\title{
Synthesis and characterization of new chiral P,O ferrocenyl ligands and catalytic application to asymmetric Suzuki-Miyaura coupling
}

Samer Bayda, ${ }^{a, b}$ Audrey Cassen, ${ }^{a, b}$ Jean-Claude Daran, ${ }^{a, b}$ Catherine Audin,,$^{a, b, c}$ Rinaldo Poli, ${ }^{a, b, d}$

$$
\text { Eric Manoury }{ }^{a, b^{*}} \text { and Eric Deydier }{ }^{a, b, c^{*}}
$$

a CNRS, LCC (Laboratoire de Chimie de Coordination), 205 route de Narbonne, BP 44099, F-31077 Toulouse Cedex 4, France.

b Université de Toulouse, UPS, INPT, F-31077 Toulouse Cedex 4, France

c IUT A Paul Sabatier, Département de Chimie, avenue Georges Pompidou, CS 20258, F-81104 Castres Cedex, France.

d Institut Universitaire de France, 103 boulevard Saint-Michel, 75005 Paris, France.

\begin{abstract}
The synthesis and characterization of a series of novel chiral P,O ferrocenyl ligands obtained from the reaction of racemic (9) or enantiomerically pure ((R)-9 or (S)-9) 2-thiodiphenylphosphino(hydroxymethyl)ferrocene with alcohols is described. The use of para-methylbenzylalcohol, ethanol and (1R,2S,5R)-menthol gives rise to three ligands (10, 11 and 12 respectively) possessing planar chirality. All compounds have been characterized by multinuclear NMR and mass spectrometry. Compounds $\mathbf{1 2}$ and 12a (the protected form of phosphine 12 with a $\mathrm{P}=\mathrm{S}$ bond) present both planar and central chirality giving rise to two diastereoisomers differing in configuration ( $\mathrm{R}$ or $\mathrm{S}$ ) of the ferrocenyl fragment. Compound (S)-12a has been characterized by single-crystal X-ray diffraction. Kinetic studies realized at three different temperatures $\left(40,50\right.$ and $\left.60^{\circ} \mathrm{C}\right)$ show good yields in the asymmetric Suzuki-Miyaura synthesis of substituted binaphthalenes using 1-naphthalenboronic acid and 1-bromo-2methylnaphthalene. The best enantioselectivity (37\% ee) was obtained with ligand (R)-12.
\end{abstract}

Keywords: Chiral P,O ferrocenyl ligands, Suzuki-Miyaura reaction, Palladium, Asymmetric synthesis, Kinetic studies.

Corresponding Authors: eric.deydier@iut-tlse3.fr, eric.manoury@1cc-toulouse.fr. 


\section{Introduction}

The Suzuki-Miyaura cross-coupling reaction is one of the most powerful methods for aryl-aryl bond formation. This reaction tolerates a great variety of functional groups and can be run under mild conditions with aryl bromides in different media (organic solvents, PEGs ${ }^{[1]}$ ionic liquids, water, etc.). In addition, boronic acids are stable, easy to synthesize and several of them are commercially available. Finally, recent catalyst development has expanded the application scope from academic areas (natural products synthesis, material design) to industrial large scale synthesis. ${ }^{[2,3,4,5]}$ Several classes of ligands such as ferrocenyl phosphines ${ }^{[6]}$ dialkylbiaryl phosphines ${ }^{[7]}, \mathrm{N}$-heterocyclic carbenes $(\mathrm{NHC}){ }^{[8]} \ldots$ have been developed to increase the catalytic activity and efficiency. ${ }^{[9]}$

However, limitations remain. A few of the main challenges are the use of cheaper aryl chlorides substrates instead of aryl bromides under mild conditions, increasing the efficiency of the asymmetric cross coupling and efficiently recycling the catalyst at the end of the reaction.

The asymmetric version of Suzuki-Miyaura reaction is of great interest because it opens direct access to biaryl compounds presenting an axial chirality (atropisomerism). The chirality of these compounds is induced by the restricted rotation around the aryl-aryl bound (Scheme 1). To exhibit atropisomerism, there must be at least three ortho substituents about the biaryl axis. Such chirality is encountered in various synthetic compounds such as BINAP and BINOL, but also in natural products presenting pharmaceutical interest such as vancomycin, steganacin, and korupensamine A (Figure 1). This high degree of steric hindrance in the reagents presents a serious challenge as it is well known that sterically congested partners can lead to poor yields in the Suzuki-Miyaura cross-coupling reaction reaction.

Three different strategies have been reported in the literature to induce axial chirality using the SuzukiMiyaura reaction: planar-to-axial induction, central-to-planar induction and chiral ligand induction (Scheme 1). ${ }^{[10]}$ However, the first two strategies necessitate a chiral substrate (planar or central chirality) which is quite restrictive in terms of potential applications. In the last one, the chirality is directly transferred by the catalyst, bearing a chiral ligand, to the product, offering a more general pathway. Substantial effort has been devoted to the development of asymmetric ligands for Suzuki-Miyaura 
applications. The first significant results were reported almost simultaneously by Buchwald ${ }^{[11]}$ and Cammidge ${ }^{[12]}$ in 2000 using various binaphthyl and ferrocenyl phosphine ligands $(\mathbf{1}, \mathbf{2}$ and $\mathbf{3}$ in Figure 2, for example). Since these pioneering reports, various ligands structures have been investigated (Figure 2). Bidendate $(\mathrm{P}, \mathrm{X})$-donor ligands $(\mathrm{X}=\mathrm{N}, \mathrm{P})$ are probably the most commonly used ones, allowing to reach high ee (ee>90\%). One example involving palladium nanoparticles has also been reported by Fujihara et al. in 2008, using the diphosphine (S)-diop, but lower enantiomeric excesses were obtained (17-69\% ee). ${ }^{[13]}$ The scope of available ligands has been recently enlarged by Lassaleta et al. reporting the efficient application of C2-symetric bis-hydrazone ligands, (5), (70-98\% ee). ${ }^{[14]}$ In 2010, Labande et al. published the first example of asymmetric Suzuki Miyaura coupling using a planar chiral ferrocenyl phosphineNHC (7, NHC: N-heterocyclic carbene) bidendate ligand (40\% ee). ${ }^{[15]}$ Since then, other type of efficient chiral NHC ligands have reported by Künding, (8), ${ }^{[16]}$ and Dorta ${ }^{[17]}$. Monophosphines bound to helical polyquinoxaline or centrally chiral at the phosphorus atom, reported respectively by Suginome ${ }^{[18]}$ and Tang, ${ }^{[19]}$ were also successfully employed in this asymmetric process giving ee in the $70-94 \%$ range. One recyclable system was also reported by Uozomi et al. using a grafted polymer with a chiral imidazo-indole phosphine. The catalytic reactions were run in water at $80^{\circ} \mathrm{C}$, with bromide and chloride binaphthyl reagent, with good conversions and enantioselectivities $\left(88-94 \%\right.$ ee). ${ }^{[20]}$

In spite of these successful applications, control of the asymmetric Suzuki-Miyaura coupling remains difficult because of its high sensitivity to the reaction medium (substrate, reagents, solvent) and also because no ligand really emerges as universal. Amongst the various ligands reported in literature for this reaction, those with a $(\mathrm{P}, \mathrm{O})$-donor set were poorly studied. However, recently published work has shown that new atropoisomeric $(\mathrm{P}, \mathrm{O})$ ligands could compete with the best ligands, allowing excellent selectivities (ee up to 97\%). ${ }^{[21]}$ This result encouraged us to investigate the efficiency of a few $(\mathrm{P}, \mathrm{O})$ ferrocenyl ligands recently synthesized in the group, which have shown good activity in the Suzuki-Miyaura reaction, ${ }^{[22]}$ in their optically pure version. The possibility to easily modify the electronic and steric properties of these ligands by judicious choice of the substituents has proven extremely useful to optimize catalytic reactions. Indeed, a good balance between the steric hindrance of the ligand and the reagents is necessary to promote 
the reaction. Moreover, hemilability is of particular interest in catalysis, as the ligands exhibiting this phenomenon generally allow the formation of reactive sites while improving the catalyst stability. However, the ability of chiral ligands to undergo rapid association/dissociation processes may be a problem in asymmetric catalysis, when the reaction selectivity is controlled by the metal stereochemistry.

Preliminary experiments have shown that compound $\mathbf{1 0}$ (Figure 3) yields good activity in the Suzuki-Miyaura coupling of phenylboronic acid with bromobenzene $(98 \%$ conversion in two hours at $70^{\circ} \mathrm{C}$ in dioxane) ${ }^{[22]}$ compared to other $(\mathrm{P}, \mathrm{O})$ ferrocenyl phosphines reported in literature. ${ }^{[23,24]}$ Here we report the synthesis and characterisation of optically pure R-10 and of new P,O ferrocenyl ligands using less crowded (11 from ethanol) or more crowded alcohol (12 from (1R,2S,5R)-menthol ), in order to study the influence of the steric hindrance around the oxygen atom on the catalytic performances. The application of these ligands in asymmetric Suzuki-Miyaura catalysis is studied at various temperatures using the coupling of 2-methyl 1-bromonaphtalene with naphthylboronic acid as model (Scheme 2).

\section{Results and Discussion}

\section{1 - Ligands Synthesis and caracterisation}

The three $(\mathrm{P}, \mathrm{O})$ ferrocenyl phosphine-ethers were prepared by a two-step synthesis from 2thiodiphenylphosphino(hydroxymethyl)ferrocene, 9 (Scheme 3). The sulfur atom protects the phosphine function from air oxidation allowing air manipulation. This precursor can be prepared in multigram quantities and isolated either as a racemic mixture or in an enantiomerically pure form, opening direct access to planar chiral ligands. ${ }^{[25]}$ Its functionalization can be performed in a one-pot process by successive additions of a strong acid $\left(\mathrm{HBF}_{4}\right)$ and the appropriate alcohol. Benzyl alcohol, ethanol and (1R,2S,5R)-menthol have been successively used (Figure 3), giving rise to the protected ligands 10a, 11a and 12a, respectively. The reactions were easily monitored through the ${ }^{13} \mathrm{C} N M R$ chemical shift of the $\mathrm{Cp}_{\mathrm{CH}} \mathrm{H}_{2} \mathrm{O}$ carbon, which moved from $58.5 \mathrm{ppm}$ to $>65 \mathrm{ppm}$ (Table 1). Compound 11a was only synthesized as a racemic mixture from 9, whereas (R)-10a, (R)-12a and (S)-12a were prepared from the enantiomeric pure (R)-9 or (S)-9. The use of the chiral (1R,2S,5R)-menthol gives rise to (R)-12 and (S)- 
12 as two different diastereoisomers, differing respectively by the $\mathrm{R}$ or $\mathrm{S}$ configuration of the ferrocenyl fragment. All of these intermediates have been characterized by multinuclear NMR and mass spectrometry.

Crystallization of (S)-12a allowed its structure to be determined by single-crystal X-ray diffraction. The molecule (Figure 4) is built up from a ferrocenyl moiety in which one $\mathrm{Cp}$ ring is $(1,2)$ substituted by a sulfur protected diphenylphosphino group and by a menthyloxomethyl group yielding planar chirality with an $\mathrm{S}$ configuration. The sulphur atom is exo with respect to the $\mathrm{Cp}$ ring with a distance from the ring plane of $1.149(1) \AA$. The $\mathrm{P}(1), \mathrm{C}(21)$ and $\mathrm{O}(2)$ atoms deviate from the ring by $-0.071(1) \AA$, $-0.0071(3)$ and $-0.005(2)$, respectively. This conformation differs from that of the related compound, 1(diphenylphosphinothioyl)-2-[(4-methylphenyl)methoxymethyl] ferrocene, ${ }^{[26]}$ in which the $C(2)-C(21)-$ $\mathrm{O}(2)$ plane is nearly perpendicular to the $\mathrm{Cp}$ ring. The $\mathrm{Cp}$ rings within the ferrocene moiety have eclipsed conformation with a twist angle of $1.4(2)^{\circ}$. These rings are not perfectly parallel with respect to each other, with a dihedral angle of $3.4(2)^{\circ}$. Selected structural parameters and bond distances and angles are given in Table 2 and 3 respectively.

The phosphine function can be recovered by deprotection with $\mathrm{P}\left(\mathrm{NMe}_{2}\right)_{3}$ in refluxing toluene. This reaction is easily monitored by ${ }^{31} \mathrm{P}$ NMR as a $60 \mathrm{ppm}$ shift between the free and protected phosphines is observed (Table 1). Ligands (R)-10, 11, (R)-12 and (S)-12 were obtained in good yields as orange waxy solids after flash chromatography and were fully characterized by mass spectrometry and multinuclear NMR. In this series, the steric hindrance on the oxygen atom changes substantially from 11 to 10 and then to the crowded menthol-based ligands 12.

\section{2 - Application in asymmetric Suzuki-Miyaura coupling}

In our investigation of the asymmetric Suzuki-Miyaura reaction, we have chosen the coupling between 1-naphthalenboronic acid and 1-bromo-2-methylnaphthalene as a model to directly compare with previously published work. ${ }^{[11-13,15 a, 17,22]}$ According to a previously optimized protocol, the reactions were 
carried out with cesium carbonate as base, $\mathrm{Pd}_{2}(\mathrm{dba})_{3}(1 \%$ molar of $\mathrm{Pd})$ as metal precursor and $1.2 \mathrm{~mol} \%$ ligand (Scheme 2). ${ }^{[22]}$

All catalytic studies were carried out in toluene. This low polarity solvent has weak coordinating power, encouraging coordination of both the phosphorus and oxygen atoms of the ligand for a better chirality transfer. One can notice that the first published asymmetric applications in Suzuki-Miyaura crosscoupling with $(\mathrm{P}, \mathrm{O})$ ferrocenyl ligands were realized in coordinating polar solvents $\left(\mathrm{DME}, \mathrm{DME}-\mathrm{H}_{2} \mathrm{O}\right.$, dioxane...) and the ee were $<20 \% .^{[12,27,28]}$ On the other hand, Qiu and Tang have recently reported ee up to $96 \%$ working in toluene with MOP-type ligands $\left(\mathrm{C}_{2}\right.$ symmetry - 6 figure 2$)$ and dialkylbiarylphosphine (chiral phosphorus) respectively. ${ }^{[19,21]}$ Bidendate coordination of the $(\mathrm{P}, \mathrm{O})$ ligand should help to control the transition states geometry allowing a better control of the product axial chirality.

Mild reaction conditions are also crucial for high enantioselectivity as asymmetric reactions are under kinetic control. We have investigated the reaction of Scheme 2 at three different temperatures (40, 50 and $60^{\circ} \mathrm{C}$ ) using the enantiopure ligands $(\mathrm{R})-\mathbf{1 0}$ and $(\mathrm{R})-\mathbf{1 2}$ and racemic 11. Aliquots withdrawn at different times were analyzed by NMR for conversion determination and by chiral HPLC for ee measurement after workup of the crude reaction mixture. Conversions versus time plots are reported in figure 5.

As expected, the reaction rate increases with temperature whatever the ligand used. With 11, for instance, a $97 \%$ conversion is obtained after only 30 minutes at $60^{\circ} \mathrm{C}$, whereas 2 hours are necessary to reach a similar conversion at $50^{\circ} \mathrm{C}$ and the conversion remained lower than $90 \%$ after 48 hours at $40^{\circ} \mathrm{C}$. One can also notice the influence of steric hindrance of the ligand on the catalytic activity. The reaction rates are lower with the more sterically hindered benzyl and "menthol" substituted ligands (R)-10 and (R)-12 than with the less hindered ethyl substituted 11. However, the activity remains good, as almost $90 \%$ conversion are still observed after only 1 hour at $60^{\circ} \mathrm{C}(v s .30$ minutes for 11$)$. At lower temperatures, the conversion remained between 75 and $90 \%$ after 48 hours, again slightly lower than with ligand 11 (90\% conversion). Compared to other $(\mathrm{P}, \mathrm{O})$ ferrocenyl ligands used in asymmetric Suzuki-Miyaura reaction, ${ }^{[12,28]}$ compounds $(\mathrm{R})-\mathbf{1 0}$ and (R)-12 present good activity allowing milder reaction conditions. 
The ee determined on the recovered product at the end of the reaction are reported in table 4 . Whereas ligand $(\mathrm{R})-\mathbf{1 0}$ afforded nearly the same ee at all temperatures, $(\mathrm{R})-\mathbf{1 2}$ gave the expected ee increase upon decreasing the temperature. The $37 \%$ ee obtained at $40^{\circ} \mathrm{C}$ is, to our knowledge, one of the best results obtained with a $(\mathrm{P}, \mathrm{O})$ ferrocenyl ligand.

\section{Conclusions}

We have reported herein the synthesis and characterization of new chiral P,O ferrocenyl ligands, bearing planar and central chirality, with different steric hindrance on the oxygen atom. Their application to the asymmetric Suzuki-Miyaura cross-coupling reactions was studied using the coupling of 1naphthalenboronic acid and 1-bromo-2-methylnaphthalene as a model reaction. The activity and selectivity have been investigated for each ligand at three different temperatures $\left(40,50\right.$ and $\left.60^{\circ} \mathrm{C}\right)$. Ligand (R)-12 afforded a 75\% yield of coupling product with $37 \%$ ee at $40{ }^{\circ} \mathrm{C}$ in toluene. This is, to our knowledge, one of the best selectivities reported for a $(\mathrm{P}, \mathrm{O})$ ferrocenyl ligand in the asymmetric SuzukiMiyaura cross-coupling reaction. This selectivity remains low compared to the best ligands reported in literature, but this is a preliminary study and the numerous factors influencing dramatically the efficiency of a catalyst (solvent, palladium precursors, substituents of the coupling partners ${ }^{[29]}$, etc.), leave numerous avenues of exploration for optimization.

\section{Material and methods}

\section{1 - General Considerations.}

All reactions were carried out using conventional Schlenk techniques under an atmosphere of argon. Thin layer chromatography and flash chromatography were carried out on Merck Kieselgel 60F254 precoated aluminum plates and on Merck Kieselgel 60, respectively. Solvents were dried by conventional methods before use. $\mathrm{HBF}_{4} \cdot \mathrm{OEt}_{2}$ solution (Sigma-Aldrich), $\mathrm{P}\left(\mathrm{NMe}_{2}\right)_{3}$ (Alfa Aesar), 1-naphthalenboronic acid (Alfa Aesar) and 1-bromo-2-methylnaphthalene (Alfa Aesar) were used as received without further purification. Racemic and enantiomerically pure 2-thiodiphenylphosphino(hydroxymethyl)-ferrocene, 9, (S)-9 and (R)-9, were synthesized according to the published procedures. ${ }^{[30]}$ The HPLC analyses were realized with 
a SHIMADZU LC2010AHT chromatograph equipped with a UV-Vis detector and a chiral OJ column $(0.46 \mathrm{~cm} \times 25 \mathrm{~cm})$, using an isopropanol/hexane solvent mixture as eluent. The NMR analyses were performed on a Bruker AV500 instrument. The spectra were referenced internally using the signal from the residual solvent for ${ }^{1} \mathrm{H}$ and ${ }^{13} \mathrm{C}$, and externally using $85 \% \mathrm{H}_{3} \mathrm{PO}_{4}$ for ${ }^{31} \mathrm{P}$. Chemical shifts and coupling constants are given in ppm and Hertz respectively. The following abbreviations are used: s: singlet; d: doublet; t: triplet; quint: quintuplet; m: multiplet; br: broad; quat: quaternary. The mass spectral analyses (GCT 1er Waters for DCI, CH4; UPLC Xevo G2 Q TOF (Waters) for $\mathrm{ES}^{+}$) were performed by “Service commun de spectrométrie de masse'” of the Université Paul-Sabatier, Toulouse (France).

\section{2 - X-Ray structural analyses.}

A single crystal of compound (S)-12a was mounted under inert perfluoropolyether at the tip of glass fiber and cooled in the cryostream of an Oxford-Diffraction XCALIBUR CCD diffractometer. The structure was solved by direct methods (SIR97) ${ }^{[31]}$ and refined by least-squares procedures on $F^{2}$ using SHELXL-2013 ${ }^{[32]}$. All $\mathrm{H}$ atoms attached to carbon were introduced in the calculations at idealised positions and treated as riding models. The absolute configuration was determined by refining the Flack's parameter. ${ }^{[33]}$ The drawing of the molecules was realised with the help of ORTEP32. ${ }^{[34]}$ Crystal data and refinement parameters are shown in Table 2. Bond distances and bond angles are presented in Table 3.

\subsection{Syntheses}

4.3.1 Synthesis and characterization of compound (R)-10a -In a Schlenk tube, $0.75 \mathrm{~g}$ of (R)-9 (1.74 mmol) was dissolved in $8 \mathrm{~mL}$ of dry dichloromethane. A 54\% solution of tetrafluoroboric acid in ether $(0.73 \mathrm{~mL}, 5.30 \mathrm{mmol})$ was then added. After $1 \mathrm{~min}$ stirring, a solution of $2.5 \mathrm{~g}$ of 4-methylbenzylalcohol (20.5 mmol) in $8 \mathrm{~mL}$ of dry dichloromethane was added. After $1 \mathrm{~min}$ of stirring, the crude material was filtered through silica gel with ether as eluent. After evaporation of the solvent, $0.4 \mathrm{~g}$ of $(R)-10 \boldsymbol{a}$ was obtained as a yellow solid (yield $=43 \%) .{ }^{1} \mathrm{H}$ NMR $\left(200.1 \mathrm{MHz}, \mathrm{CDCl}_{3}\right), \delta(\mathrm{ppm}): 7.90-7.65(4 \mathrm{H}, \mathrm{m}$ : $\left.\mathrm{PPh}_{2}\right)$; 7.52-7.34 (6H, m: PPh $) ; 7.05$ (2H, d, J = 7.9 Hz: Ph); 6.95 (2H, d, J = 7.9 Hz: Ph); 4.89 (1H, d, J $\left.=10.9 \mathrm{~Hz}: \mathrm{CpCH}_{2}\right) ; 4.66(1 \mathrm{H}, \mathrm{m}:$ subst $\mathrm{Cp}) ; 4.45\left(1 \mathrm{H}, \mathrm{d}, \mathrm{J}=10.9 \mathrm{~Hz}: \mathrm{CpCH}_{2}\right) ; 4.35$ (1H, m: subst Cp); 
4.33 (5H, s: Cp); 4.29 (2H, d: $\left.2.9 \mathrm{~Hz}: \mathrm{PhCH}_{2} \mathrm{O}\right) ; 3.85(1 \mathrm{H}, \mathrm{m}:$ subst $\mathrm{Cp}) ; 2.33\left(3 \mathrm{H}, \mathrm{m}: \mathrm{CH}_{3}\right) .{ }^{13} \mathrm{C}$ NMR (50.3 MHz, $\left.\mathrm{CDCl}_{3}\right), \delta(\mathrm{ppm}): 136.8(\mathrm{~s}:$ quat $\mathrm{Ph}) ; 135.4$ (s: quat $\left.\mathrm{Ph}\right) ; 134.8\left(\mathrm{~d}, \mathrm{~J}_{\mathrm{PC}}=87.1 \mathrm{~Hz}:\right.$ quat $\left.\mathrm{PPh}_{2}\right)$ 133.6 (d, JPC $=86.1 \mathrm{~Hz}:$ quat $\left.\mathrm{PPh}_{2}\right) ; 132.2\left(\mathrm{~d}, \mathrm{~J}_{\mathrm{PC}}=10.7 \mathrm{~Hz}: \mathrm{PPh}_{2}\right) ; 132.1\left(\mathrm{~d}, \mathrm{~J}_{\mathrm{PC}}=10.7 \mathrm{~Hz}: \mathrm{PPh}_{2}\right) ; 131.2$ $\left(\mathrm{d}, \mathrm{J}_{\mathrm{PC}}=2.2 \mathrm{~Hz}: \mathrm{PPh}_{2}\right) ; 131.1\left(\mathrm{~d}, \mathrm{~J}_{\mathrm{PC}}=2.2 \mathrm{~Hz}: \mathrm{PPh}_{2}\right) ; 128.8(\mathrm{~s}: \mathrm{Ph}) ; 128.1\left(\mathrm{~d}, \mathrm{~J}_{\mathrm{PC}}=12.3 \mathrm{~Hz}: \mathrm{PPh}_{2}\right) ; 128.0$ $\left(\mathrm{d}, \mathrm{J}_{\mathrm{PC}}=12.3 \mathrm{~Hz}: \mathrm{PPh}_{2}\right) ; 127.7(\mathrm{~s}: \mathrm{Ph}) ; 88.3\left(\mathrm{~d}, \mathrm{~J}_{\mathrm{PC}}=12.1 \mathrm{~Hz}:\right.$ quat Cp); $75.2\left(\mathrm{~d}, \mathrm{~J}_{\mathrm{PC}}=12.5 \mathrm{~Hz}:\right.$ subst Cp); $75.6\left(\mathrm{~d}, \mathrm{~J}_{\mathrm{PC}}=94.7 \mathrm{~Hz}:\right.$ quat $\left.\mathrm{Cp}\right) ; 74.5\left(\mathrm{~d}, \mathrm{~J}_{\mathrm{PC}}=9.4 \mathrm{~Hz}\right.$ : subst Cp); $72.4\left(\mathrm{~s}, \mathrm{PhCH}_{2} \mathrm{O}\right) ; 70.7$ (s: Cp); 69.4 $\left(\mathrm{d}, \mathrm{J}_{\mathrm{PC}}=10.4 \mathrm{~Hz}\right.$ : subst Cp); $66.7\left(\mathrm{~s}: \mathrm{CpCH}_{2} \mathrm{O}\right) ; 21.3\left(\mathrm{~s}: \mathrm{CH}_{3}\right) .{ }^{31} \mathrm{P} \mathrm{NMR}\left(81.0 \mathrm{MHz}, \mathrm{CDCl}_{3}\right), \delta(\mathrm{ppm}):$ 43.1. HR MS (DCI CH 4$), \mathrm{C}_{31} \mathrm{H}_{29} \mathrm{OPSFe}$, calcd. mass [M]: 536.1026; exp. mass [M]: 536.1039.

4.3.2 Synthesis and characterization of compound (R)-10 - In a Schlenk tube, $350 \mathrm{mg}$ of $(R)-10 a(0.22$ mmol) were dissolved in $5 \mathrm{~mL}$ of dry toluene together with $0.75 \mathrm{~mL}$ of tris(dimethylamino)phosphine (3.9 mmol). The solution was kept at reflux overnight under argon. After cooling back to room temperature, the solution was evaporated in vасио. The crude residue was purified under argon by flash chromatography on silica gel with dichloromethane as eluent. After evaporation of the solvent, $235 \mathrm{mg}$ of $(R)-10$ were obtained as an orange waxy solid (yield $=70 \%) .{ }^{1} \mathrm{H} \mathrm{NMR}\left(200.1 \mathrm{MHz}, \mathrm{CDCl}_{3}\right), \delta(\mathrm{ppm})$ : 7.67-7.58 (2H, m: $\left.\mathrm{PPh}_{2}\right) ; 7.48-7.41\left(3 \mathrm{H}, \mathrm{m}: \mathrm{PPh}_{2}\right) ; 7.32-7.29\left(5 \mathrm{H}, \mathrm{m}: \mathrm{PPh}_{2}\right) ; 7.08(2 \mathrm{H}, \mathrm{d}, \mathrm{J}=8.1 \mathrm{~Hz}$ : Ph); $6.97(2 \mathrm{H}, \mathrm{d}, \mathrm{J}=8.1 \mathrm{~Hz}: \mathrm{Ph}) ; 4.65\left(1 \mathrm{H}, \mathrm{dd}, \mathrm{J}=10.9 \mathrm{~Hz}, \mathrm{~J}_{\mathrm{PH}}=2.2 \mathrm{~Hz}: \mathrm{CpCH}_{2}\right) ; 4.60$ (1H, m: subst Cp); 4.44 (1H, d, J = 10.9 Hz: $\left.\mathrm{CpCH}_{2}\right) ; 4.37$ (2H, s: $\left.\mathrm{PhCH}_{2} \mathrm{O}\right)$; 4.36 (1H, m: subst Cp); 4.08 (5H, s: Cp); $3.83\left(1 \mathrm{H}, \mathrm{m}:\right.$ subst Cp); $2.37\left(3 \mathrm{H}, \mathrm{m}: \mathrm{CH}_{3}\right) .{ }^{13} \mathrm{C} \mathrm{NMR}\left(50.3 \mathrm{MHz}, \mathrm{CDCl}_{3}\right), \delta(\mathrm{ppm}): 140.8\left(\mathrm{~d}, \mathrm{~J}_{\mathrm{PC}}=9.3\right.$ Hz: quat $\left.\mathrm{PPh}_{2}\right) ; 138.3\left(\mathrm{~d}, \mathrm{~J}_{\mathrm{PC}}=8.2 \mathrm{~Hz}\right.$ : quat $\left.\mathrm{PPh}_{2}\right) ; 137.6(\mathrm{~s}:$ quat $\mathrm{Ph}) ; 136.2(\mathrm{~s}:$ quat $\mathrm{Ph}) ; 135.9\left(\mathrm{~d}, \mathrm{~J}_{\mathrm{PC}}=\right.$ 20.3 Hz: $\left.\mathrm{PPh}_{2}\right) ; 133.2\left(\mathrm{~d}, \mathrm{~J}_{\mathrm{PC}}=17.9 \mathrm{~Hz}: \mathrm{PPh}_{2}\right) ; 129.9\left(\mathrm{~s}: \mathrm{PPh}_{2}\right) ; 129.6(\mathrm{~s}: \mathrm{Ph}) ; 128.9\left(\mathrm{~d}, \mathrm{~J}_{\mathrm{PC}}=7.5 \mathrm{~Hz}:\right.$ $\left.\mathrm{PPh}_{2}\right) ; 128.8\left(\mathrm{~d}, \mathrm{~J}_{\mathrm{PC}}=5.7 \mathrm{~Hz}: \mathrm{PPh}_{2}\right) ; 128.5\left(\mathrm{~s}: \mathrm{PPh}_{2}\right) ; 128.4\left(\mathrm{~s}: \mathrm{PPh}_{2}\right) ; 90.1\left(\mathrm{~d}, \mathrm{~J}_{\mathrm{PC}}=24.6 \mathrm{~Hz}:\right.$ quat $\left.\mathrm{Cp}\right)$; $77.5\left(\mathrm{~d}, \mathrm{~J}_{\mathrm{PC}}=8.1 \mathrm{~Hz}\right.$ : quat Cp); $73.5\left(\mathrm{~d}, \mathrm{~J}_{\mathrm{PC}}=3.4 \mathrm{~Hz}\right.$ : subst Cp); $72.9\left(\mathrm{~s}, \mathrm{PhCH}_{2} \mathrm{O}\right) ; 72.7\left(\mathrm{~d}, \mathrm{~J}_{\mathrm{PC}}=3.7 \mathrm{~Hz}\right.$ : subst Cp); 70.6 (s: subst Cp); 70.3 (s: Cp); 68.1 (d, JPC $\left.=9.9 \mathrm{~Hz}: \mathrm{CpCH}_{2} \mathrm{O}\right) ; 22.0\left(\mathrm{~s}: \mathrm{CH}_{3}\right) .{ }^{31} \mathrm{P}$ NMR $(81.0$ $\left.\mathrm{MHz}, \mathrm{CDCl}_{3}\right), \delta(\mathrm{ppm}):-22.9\left(\mathrm{PPh}_{2}\right) . \mathrm{HR} \mathrm{MS}\left(\mathrm{DCI} \mathrm{CH}_{4}\right), \mathrm{C}_{31} \mathrm{H}_{29} \mathrm{OPFe}$, calcd. mass [M+H]: 505.1375; exp. mass $[\mathrm{M}+\mathrm{H}]: 505.1384$. 
4.3.3 Synthesis and characterization of compound 11a - In a Schlenk tube, $0.75 \mathrm{~g}$ of (R)-9 (0.24 mmol) was dissolved in $8 \mathrm{~mL}$ of dry dichloromethane. A 54\% solution of tetrafluoroboric acid in ether $(0.10 \mathrm{~mL}$, $0.73 \mathrm{mmol})$ was then added. After $1 \mathrm{~min}$ stirring, $0.6 \mathrm{~mL}$ of ethanol $(10 \mathrm{mmol})$ was added. After $1 \mathrm{~min}$ of stirring, the crude material was filtered on silica gel with ether as eluent. After evaporation of the solvent, $0.62 \mathrm{~g}$ of 11a was obtained as a yellow solid (yield $=56 \%) .{ }^{1} \mathrm{H} \mathrm{RMN}\left(400.1 \mathrm{MHz}, \mathrm{CDCl}_{3}\right), \delta(\mathrm{ppm}): 7.86-$ 7.81 (2H, m: $\left.\mathrm{PPh}_{2}\right)$; 7.72-7.66 (2H, m: $\left.\mathrm{PPh}_{2}\right) ; 7.55-7.36$ (6H, m: $\left.\mathrm{PPh}_{2}\right)$; 4.79 (1H, d, J = 10.9 Hz: $\mathrm{CpCH}_{2}$ ); 4.64 (1H, m: subst Cp); $4.38\left(1 \mathrm{H}, \mathrm{d}, \mathrm{J}=10.9 \mathrm{~Hz}: \mathrm{CpCH}_{2}\right) ; 4.35$ (5H, s: Cp); 4.32 (1H, m: subst Cp); 3.81 (1H, m: subst Cp); 3.36-3.22 (2H, m: $\left.\mathrm{OCH}_{2} \mathrm{CH}_{3}\right) ; 0.85\left(3 \mathrm{H}, \mathrm{t}, \mathrm{J}=7 \mathrm{~Hz}: \mathrm{CH}_{3} \mathrm{CH}_{2} \mathrm{O}\right) .{ }^{13} \mathrm{C} \mathrm{NMR}(100.6$ $\left.\mathrm{MHz}, \mathrm{CDCl}_{3}\right), \delta(\mathrm{ppm}): 134.8\left(\mathrm{~d}, \mathrm{~J}_{\mathrm{PC}}=87.6 \mathrm{~Hz}:\right.$ quat $\left.\mathrm{PPh}_{2}\right) ; 133.6\left(\mathrm{~d}, \mathrm{~J}_{\mathrm{PC}}=86.0 \mathrm{~Hz}:\right.$ quat $\left.\mathrm{PPh}_{2}\right) ; 132.15$ $\left(\mathrm{d}, \mathrm{J}_{\mathrm{PC}}=10.8 \mathrm{~Hz}: \mathrm{PPh}_{2}\right) ; 132.10\left(\mathrm{~d}, \mathrm{~J}_{\mathrm{PC}}=10.8 \mathrm{~Hz}: \mathrm{PPh}_{2}\right) ; 128.1\left(\mathrm{~s}: \mathrm{PPh}_{2}\right) ; 127.9\left(\mathrm{~s}: \mathrm{PPh}_{2}\right) ; 88.5\left(\mathrm{~d}, \mathrm{~J}_{\mathrm{PC}}=\right.$ 12.0 Hz: quat Cp); $75.2\left(\mathrm{~d}, \mathrm{~J}_{\mathrm{PC}}=12.7 \mathrm{~Hz}\right.$ : subst Cp); $74.8\left(\mathrm{~d}, \mathrm{~J}_{\mathrm{PC}}=95.0 \mathrm{~Hz}\right.$ : quat Cp); $74.2\left(\mathrm{~d}, \mathrm{~J}_{\mathrm{PC}}=9.4\right.$

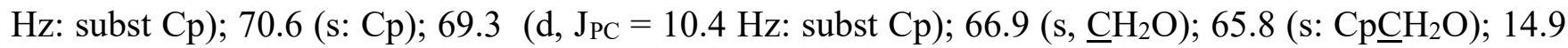
(s: $\left.\mathrm{CH}_{3}\right) .{ }^{31} \mathrm{P} \mathrm{NMR}\left(81.0 \mathrm{MHz}, \mathrm{CDCl}_{3}\right), \delta(\mathrm{ppm}): 41.9\left(\mathrm{PPh}_{2}\right)$. HR MS (DCI, $\left.\mathrm{CH}_{4}\right), \mathrm{C} 25 \mathrm{H} 25 \mathrm{OPSFe}$, masse calc. [M]: 460.0713, masse exp. [M]: 460.0716.

4.3.4 Synthesis and characterization of compound 11 - In a Schlenk tube, $124 \mathrm{mg}$ of $11 \mathrm{a}(0.27$ mmol) were dissolved in $3 \mathrm{~mL}$ of dry toluene together with $0.3 \mathrm{~mL}$ of tris(dimethylamino)phosphine (1.65 mmol). The solution was kept at reflux overnight under argon. After cooling back to room temperature, the solution was evaporated in vacuo. The crude residue was purified under argon by flash chromatography on silica gel with dichloromethane as eluent. After evaporation of the solvent, $97 \mathrm{mg}$ of 11 were obtained as an orange waxy solid (yield =84\%). ${ }^{1} \mathrm{H}$ NMR $\left(400.1 \mathrm{MHz}, \mathrm{CDCl}_{3}\right), \delta(\mathrm{ppm})$ : 7.637.57 (2H, m: $\left.\mathrm{PPh}_{2}\right) ; 7.44-7.40\left(3 \mathrm{H}, \mathrm{m}: \mathrm{PPh}_{2}\right)$; 7.26-7.23 (5H, m: $\left.\mathrm{PPh}_{2}\right)$; 4.58-4.52 (2H, m, 1H CpCH $\mathrm{CH}_{2}+$ 1H subst $\mathrm{Cp}) ; 4.38\left(1 \mathrm{H}, \mathrm{d}, \mathrm{AB}\right.$ system, $\left.\mathrm{J}=11.1 \mathrm{~Hz}: \mathrm{CpCH}_{2}\right) ; 4.32(1 \mathrm{H}, \mathrm{t}, \mathrm{J}=2.4 \mathrm{~Hz}$ : subst Cp); $4.06(5 \mathrm{H}$, s: Cp); $3.79\left(1 \mathrm{H}, \mathrm{m}\right.$ : subst Cp); 3.42-3.27 (2H, m: $\left.\mathrm{OCH}_{2} \mathrm{CH}_{3}\right) ; 0.93\left(3 \mathrm{H}, \mathrm{t}, \mathrm{J}=7.0 \mathrm{~Hz}: \mathrm{C}_{3} \mathrm{CH}_{2} \mathrm{O}\right) .{ }^{13} \mathrm{C}$ $\operatorname{NMR}\left(100.6 \mathrm{MHz}, \mathrm{CDCl}_{3}\right), \delta(\mathrm{ppm}): 139.9\left(\mathrm{~d}, \mathrm{~J}_{\mathrm{PC}}=9.6 \mathrm{~Hz}:\right.$ quat $\left.\mathrm{PPh}_{2}\right) ; 137.5\left(\mathrm{~d}, \mathrm{~J}_{\mathrm{PC}}=8.4 \mathrm{~Hz}\right.$ : quat $\left.\mathrm{PPh}_{2}\right) ; 135.1\left(\mathrm{~d}, \mathrm{~J}_{\mathrm{PC}}=21.1 \mathrm{~Hz}: \mathrm{PPh}_{2}\right) ; 132.4\left(\mathrm{~d}, \mathrm{~J}_{\mathrm{PC}}=18.0 \mathrm{~Hz}: \mathrm{PPh}_{2}\right) ; 129.1\left(\mathrm{~s}: \mathrm{PPh}_{2}\right) ; 128.1\left(\mathrm{~d}, \mathrm{~J}_{\mathrm{PC}}=7.8\right.$ 
Hz: $\left.\mathrm{PPh}_{2}\right) ; 127.8\left(\mathrm{~d}, \mathrm{~J}_{\mathrm{PC}}=7.0 \mathrm{~Hz}: \mathrm{PPh}_{2}\right) ; 127.6\left(\mathrm{~s}: \mathrm{PPh}_{2}\right) ; 89.6\left(\mathrm{~d}, \mathrm{~J}_{\mathrm{PC}}=24 . \mathrm{Hz}:\right.$ quat $\left.\mathrm{Cp}\right) ; 76.7\left(\mathrm{~d}, \mathrm{~J}_{\mathrm{PC}}=\right.$ 8.1 Hz: quat Cp); 72.5 (d, JPC $=3.7 \mathrm{~Hz}$ : subst Cp); 71.8 (d, JPC $=3.9 \mathrm{~Hz}$ : subst Cp); 69.7 (s: subst Cp); 69. (s: Cp); $67.6\left(\mathrm{~d}, \mathrm{~J}_{\mathrm{PC}}=9.8 \mathrm{~Hz}: \mathrm{Cp}_{\underline{C}} \mathrm{H}_{2} \mathrm{O}\right) ; 65.5\left(\mathrm{~s}, \mathrm{CH}_{3} \underline{\mathrm{CH}}_{2} \mathrm{O}\right) ; 14.9\left(\mathrm{~s}: \mathrm{CH}_{3}\right) .{ }^{31} \mathrm{P} \mathrm{NMR}(161.9 \mathrm{MHz}$, $\left.\mathrm{CDCl}_{3}\right), \delta(\mathrm{ppm}):-22.5$.

4.3.5 Synthesis and characterization of compounds (R)-12a and (S)-12a-This procedure was carried out in an identical manner for the two compounds and will be detailed on for the former. In a Schlenk tube, $0.100 \mathrm{~g}$ of $(\mathrm{R})-9(0.23 \mathrm{mmol})$ was dissolved in $2 \mathrm{~mL}$ of dry dichloromethane. A $54 \%$ solution of tetrafluoroboric acid in ether $(0.10 \mathrm{~mL}, 0.73 \mathrm{mmol})$ was then added. After $1 \mathrm{~min}$ stirring, 1.46 $\mathrm{g}$ of $(1 \mathrm{R}, 2 \mathrm{~S}, 5 \mathrm{R})-\mathrm{Menthol}(9.34 \mathrm{mmol})$ in $2 \mathrm{~mL}$ dichloromethane were added. After $1 \mathrm{~min}$ of stirring, the crude material was filtered on silica gel with a mixture of pentane/ether as eluent. After evaporation of the solvent, $0.35 \mathrm{~g}$ of $(\mathrm{R})-\mathbf{1 2 a}$ was obtained as a yellow solid (yield $=27 \%$ ).

Characterization of (R)-12a - ${ }^{1} \mathrm{H}$ NMR (400.3 MHz, $\left.\mathrm{CDCl}_{3}\right), \delta(\mathrm{ppm}): 7.83-7.79$ (2H, m: $\mathrm{PPh}_{2}$ ); 7.68-7.63 (2H, m: $\left.\mathrm{PPh}_{2}\right)$; 7.54-7.36 (6H, m: $\left.\mathrm{PPh}_{2}\right)$; $4.74(1 \mathrm{H}, \mathrm{m}:$ subst $\mathrm{Cp}) ; 4.72(1 \mathrm{H}, \mathrm{d}, \mathrm{J}=2.4 \mathrm{~Hz}$ : $\left.\mathrm{CpCH}_{2}\right) ; 4.71\left(1 \mathrm{H}, \mathrm{d}, \mathrm{J}=11.3 \mathrm{~Hz}: \mathrm{CpCH}_{2}\right) ; 4.33$ (1H, m: subst Cp); 4.32 (5H, s: Cp); 3.75 (1H, m: subst Cp); 2.98 (1H, td, J = $\left.10.5 \mathrm{~Hz}, \mathrm{~J}=4.4 \mathrm{~Hz}: \mathrm{CH}-\mathrm{O}) ; 2.15\left(1 \mathrm{H}, \mathrm{m}: \underline{\mathrm{C}}_{2} \mathrm{CH}-\mathrm{O}\right) ; 1.72\left(1 \mathrm{H}, \mathrm{m:} \underline{\mathrm{H}}_{(\mathrm{CH}}\right)_{2}\right)$; $1.58\left(2 \mathrm{H}, \mathrm{m}: \mathrm{CH}_{2} \mathrm{CHCH}_{3}\right) ; 1.32\left(1 \mathrm{H}, \mathrm{m}: \mathrm{CH}_{2} \mathrm{CHCH}-\mathrm{O}\right) ; 1.28\left(1 \mathrm{H}, \mathrm{m}: \mathrm{CH}_{2} \mathrm{CHCH}-\mathrm{O}\right) ; 0.92$ (1H, m: $\left.\mathrm{CHCH}\left(\mathrm{CH}_{3}\right)_{2}\right) ; 0.9\left(3 \mathrm{H}, \mathrm{d}, \mathrm{J}=7.1 \mathrm{~Hz}: \mathrm{CH}_{3} \mathrm{CH}\left(\mathrm{CH}_{2}\right)_{2}\right) ; 0.78\left(1 \mathrm{H}, \mathrm{m}: \mathrm{CH}_{2} \mathrm{CH}-\mathrm{O}\right) ; 0.66(3 \mathrm{H}, \mathrm{d}, \mathrm{J}=7.1 \mathrm{~Hz}$ : $\left.\left(\underline{\mathrm{C}}_{3}\right)_{2} \mathrm{CH}\right) ; 0.47\left(3 \mathrm{H}, \mathrm{d}, \mathrm{J}=7.1 \mathrm{~Hz}:\left(\mathrm{C}_{3}\right)_{2} \mathrm{CH}\right) .{ }^{13} \mathrm{C} \mathrm{NMR}\left(125.8 \mathrm{MHz}, \mathrm{CDCl}_{3}\right), \delta(\mathrm{ppm})$ : invisibles $135.11\left(\mathrm{~d}, \mathrm{~J}_{\mathrm{PC}}=87.2 \mathrm{~Hz}:\right.$ quat $\left.\mathrm{PPh}_{2}\right) ; 133.82\left(\mathrm{~d}, \mathrm{~J}_{\mathrm{PC}}=85.9 \mathrm{~Hz}:\right.$ quat $\left.\mathrm{PPh}_{2}\right) ; 132.18\left(\mathrm{~d}, \mathrm{~J}_{\mathrm{PC}}=10.7: \mathrm{PPh}_{2}\right)$; $131.96\left(\mathrm{~d}, \mathrm{~J}_{\mathrm{PC}}=10.7 \mathrm{~Hz}: \mathrm{PPh}_{2}\right) ; 131.14\left(\mathrm{~d}, \mathrm{~J}_{\mathrm{PC}}=2.9 \mathrm{~Hz}: \mathrm{PPh}_{2}\right) ; 131.09\left(\mathrm{~d}, \mathrm{~J}_{\mathrm{PC}}=2.9 \mathrm{~Hz}: \mathrm{PPh}_{2}\right) ; 128.16$ $\left(\mathrm{d}, \mathrm{J}_{\mathrm{PC}}=12.3 \mathrm{~Hz}: \mathrm{PPh}_{2}\right) ; 127.92\left(\mathrm{~d}, \mathrm{~J}_{\mathrm{PC}}=12.3 \mathrm{~Hz}: \mathrm{PPh}_{2}\right) ; 89.77$ (d, JPC $=11.8 \mathrm{~Hz}:$ quat Cp); 78.20 (s: CHO); $74.66\left(\mathrm{~d}, \mathrm{~J}_{\mathrm{PC}}=12.8 \mathrm{~Hz}\right.$ : quat Cp); $74.44(\mathrm{~d}, \mathrm{~J}=9.3 \mathrm{~Hz}$ : subst Cp); 73.64 (d, J = 95.2 Hz: subst Cp); 70.72 (s: Cp); 69.70 (s: subst Cp); 69.59 (d, J = 10.3 Hz: subst Cp); 64.06 (s: $\mathrm{CpCH}_{2}$ ); 48.17 (s: CHCHO); 40.10 (s: $\left.\mathrm{CH}_{2} \mathrm{CH}-\mathrm{O}\right) ; 34.61\left(\mathrm{~s}: \mathrm{CH}_{2} \mathrm{CHCH}_{3}\right) ; 31.38\left(\mathrm{~s}: \mathrm{CHCH}_{3}\right) ; 24.94\left(\mathrm{~s}: \mathrm{CH}\left(\mathrm{CH}_{3}\right)_{2}\right) ; 23.04$ (s: $\left.\mathrm{CH}_{2} \mathrm{CHCH}-\mathrm{O}\right) ; 22.44$ (s: $\left.\mathrm{CH}_{3} \mathrm{CH}\right) ; 21.09$ (s: $\left.\left(\mathrm{CH}_{3}\right)_{2} \mathrm{CH}\right) ; 16.01$ (s: $\left.\left(\mathrm{CH}_{3}\right)_{2} \mathrm{CH}\right) .{ }^{31} \mathrm{P}$ NMR $(202.5 \mathrm{MHz}$, $\mathrm{CDCl}_{3}$ ), $\delta$ (ppm): 41.5. HR MS (DCI, CH4): 570.1800 (calculated mass for $\mathrm{C}_{33} \mathrm{H}_{39} \mathrm{OPSFe}: 570.1809$ ). 
Characterization of (S)-12a - ${ }^{1} \mathrm{H}$ NMR (500.3 MHz, $\left.\mathrm{CDCl}_{3}\right), \delta(\mathrm{ppm}):$ 7.86-7.81 (2H, m: $\left.\mathrm{PPh}_{2}\right)$; 7.69-7.64 (2H, m: $\left.\mathrm{PPh}_{2}\right)$; 7.55-7.35 (6H, m: $\left.\mathrm{PPh}_{2}\right)$; 4.79 (1H, d, J = 11.4 Hz: CpCH 2$) ; 4.75$ (1H, m: subst Cp) ; 4.49 (1H, d, J = 11.4 Hz: $\left.\mathrm{CpCH}_{2}\right)$; 4.34 (5H, s: Cp); 4.31 (1H, m: subst Cp); 3.74 (1H, m: subst Cp); $3.06(1 \mathrm{H}, \mathrm{td}, \mathrm{J}=10.3 \mathrm{~Hz}, \mathrm{~J}=3.8 \mathrm{~Hz}: \mathrm{CH}-\mathrm{O}) ; 2.25\left(1 \mathrm{H}, \mathrm{m}: \underline{\mathrm{C}}_{2} \mathrm{CH}-\mathrm{O}\right) ; 1.79\left(1 \mathrm{H}, \mathrm{m:} \underline{\mathrm{H}}\left(\mathrm{CH}_{3}\right)_{2}\right) ; 1.57$ $\left(2 \mathrm{H}, \mathrm{m}: \mathrm{CH}_{2} \mathrm{CHCH}_{3}\right) ; 1.24\left(1 \mathrm{H}, \mathrm{m}: \mathrm{CH}_{2} \mathrm{CHCH}-\mathrm{O}\right) ; 1.11\left(1 \mathrm{H}, \mathrm{m}: \mathrm{CH}_{2} \mathrm{CHCH}-\mathrm{O}\right) ; 0.92$ (1H, m: $\left.\mathrm{CHCH}\left(\mathrm{CH}_{3}\right)_{2}\right) ; 0.91\left(3 \mathrm{H}, \mathrm{d}, \mathrm{J}=7.1 \mathrm{~Hz}: \mathrm{CH}_{3} \mathrm{CH}\left(\mathrm{CH}_{2}\right)_{2}\right) ; 0.78\left(1 \mathrm{H}, \mathrm{m}: \mathrm{CH}_{2} \mathrm{CH}-\mathrm{O}\right) ; 0.83(3 \mathrm{H}, \mathrm{d}, \mathrm{J}=7.0$ Hz: $\left.\left(\mathrm{CH}_{3}\right)_{2} \mathrm{CH}\right) ; 0.80\left(3 \mathrm{H}, \mathrm{d}, \mathrm{J}=6.5 \mathrm{~Hz}:\left(\mathrm{C}_{3}\right)_{2} \mathrm{CH}\right) .{ }^{13} \mathrm{C} \mathrm{NMR}\left(125.8 \mathrm{MHz}, \mathrm{CDCl}_{3}\right), \delta(\mathrm{ppm}): 133.58$ $\left(\mathrm{d}, \mathrm{J}_{\mathrm{PC}}=86.1 \mathrm{~Hz}:\right.$ quat $\left.\mathrm{PPh}_{2}\right) ; 133.57\left(\mathrm{~d}, \mathrm{~J}_{\mathrm{PC}}=85.9 \mathrm{~Hz}:\right.$ quat $\left.\mathrm{PPh}_{2}\right) ; 132.14\left(\mathrm{~d}, \mathrm{~J}_{\mathrm{PC}}=10.7: \mathrm{PPh}_{2}\right) ; 132.08$ $\left(\mathrm{d}, \mathrm{J}_{\mathrm{PC}}=10.7 \mathrm{~Hz}: \mathrm{PPh}_{2}\right) ; 131.20\left(\mathrm{~d}: \mathrm{J}_{\mathrm{PC}}=2.1 \mathrm{~Hz}: \mathrm{PPh}_{2}\right) ; 131.08\left(\mathrm{~d}: \mathrm{J}_{\mathrm{PC}}=2.1 \mathrm{~Hz}: \mathrm{PPh}_{2}\right) ; 128.19\left(\mathrm{~d}, \mathrm{~J}_{\mathrm{PC}}=\right.$ 12.5 Hz: $\left.\mathrm{PPh}_{2}\right) ; 127.98\left(\mathrm{~d}, \mathrm{~J}_{\mathrm{PC}}=12.5 \mathrm{~Hz}: \mathrm{PPh}_{2}\right) ; 90.15$ (d, JPC $=12.0 \mathrm{~Hz}$ : quat Cp); 79.36 (s: CH-O); 74.55 (d, J = 12.8 Hz: quat Cp); 73.65 (d, J = 95.2 Hz: subst Cp); 73.56 (d, J=9.4 Hz: subst Cp); 70.71 (s: Cp); $69.21\left(\mathrm{~d}, \mathrm{~J}=10.1 \mathrm{~Hz}\right.$ : subst Cp); 65.39 (s: $\left.\mathrm{CpCH}_{2}\right) ; 48.43$ (s: $\left.\mathrm{CHCH}-\mathrm{O}\right) ; 40.14$ (s: $\left.\mathrm{CH}_{2} \mathrm{CH}-\mathrm{O}\right) ; 34.59$ (s: $\left.\mathrm{CH}_{2} \mathrm{CHCH}_{3}\right) ; 31.41$ (s: $\left.\mathrm{CHCH}_{3}\right) ; 25.69$ (s: $\left.\mathrm{CH}\left(\mathrm{CH}_{3}\right)_{2}\right) ; 23.32$ (s: $\left.\mathrm{CH}_{2} \mathrm{CHCH}-\mathrm{O}\right) ; 22.3$ (s: $\left.\mathrm{CH}_{3} \mathrm{CH}\right) ; 21.11$ (s: $\left.\left(\mathrm{CH}_{3}\right)_{2} \mathrm{CH}\right) ; 16.45$ (s: $\left.\left(\mathrm{CH}_{3}\right)_{2} \mathrm{CH}\right) .{ }^{31} \mathrm{P} \mathrm{NMR}\left(202.5 \mathrm{MHz}, \mathrm{CDCl}_{3}\right), \delta(\mathrm{ppm}): 41.8 \mathrm{HR} \mathrm{MS}$ (DCI, CH4): 570.1800 (calculated mass for C33H39OPSFe: 570.1809).

4.3.6 Synthesis and characterization of compound (R)-12 - In a Schlenk tube, 86 mg of (R)-12a $(0.15 \mathrm{mmol})$ were dissolved in $2 \mathrm{~mL}$ of dry toluene together with $\mathrm{P}\left(\mathrm{NMe}_{2}\right)_{3}(0.25 \mathrm{~mL}, 1.38 \mathrm{mmol})$. The solution was kept at reflux overnight under argon and then evaporated in vacuo after cooling back to room temperature. The crude residue was purified under argon by flash chromatography on silica gel with dichloromethane as eluent. After evaporation of the solvent, $25 \mathrm{mg}$ of $(R)-12$ were obtained as an orange waxy solid (yield = 31\%). ${ }^{1} \mathrm{H}$ NMR $\left(500.3 \mathrm{MHz}, \mathrm{CDCl}_{3}\right), \delta(\mathrm{ppm}): 7.6-7.56\left(2 \mathrm{H}, \mathrm{m}: \mathrm{PPh}_{2}\right) ; 7.41-7.38$ (3H, m: $\left.\mathrm{PPh}_{2}\right) ; 7.24-7.19\left(5 \mathrm{H}, \mathrm{m}: \mathrm{PPh}_{2}\right) ; 4.62\left(1 \mathrm{H}, \mathrm{m}:\right.$ subst Cp); $4.60\left(1 \mathrm{H}, \mathrm{d}, \mathrm{J}=10.5 \mathrm{~Hz}: \mathrm{CpCH}_{2}\right) ; 4.41$ $\left(1 \mathrm{H}, \mathrm{dd}, \mathrm{J}=10.5 \mathrm{~Hz}, \mathrm{~J}_{\mathrm{PH}}=2.7 \mathrm{~Hz}: \mathrm{CpCH}_{2}\right) ; 4.34(1 \mathrm{H}, \mathrm{m}:$ subst Cp); 4.01 (5H, s: Cp); 3.83 (1H, m: subst Cp); 3.01 (1H, td, J = 10.5 Hz, 4.0 Hz: CH-O); 2.19 (1H, m: $\left.\underline{\mathrm{H}}_{2} \mathrm{CH}-\mathrm{O}\right) ; 1.72\left(1 \mathrm{H}, \mathrm{m:} \underline{\mathrm{H}}\left(\mathrm{CH}_{3}\right)_{2}\right) ; 1.57$ $\left(1 \mathrm{H}, \mathrm{m}: \mathrm{CH}_{2} \mathrm{CHCH}_{3}\right) ; 1.50\left(1 \mathrm{H}, \mathrm{m}: \mathrm{CH}_{2} \mathrm{CHCH}-\mathrm{O}\right) ; 1.12\left(1 \mathrm{H}, \mathrm{m}: \mathrm{CHCH}_{3}\right) ; 1.06\left(1 \mathrm{H}, \mathrm{m}: \mathrm{C} \underline{\mathrm{HCH}}\left(\mathrm{CH}_{3}\right)_{2}\right)$; $0.91\left(3 \mathrm{H}, \mathrm{d}, \mathrm{J}=6.5 \mathrm{~Hz}: \mathrm{CH}_{3} \mathrm{CH}\right) ; 0.81\left(1 \mathrm{H}, \mathrm{m}: \underline{\mathrm{C}}_{2} \mathrm{CH}-\mathrm{O}\right) ; 0.81\left(1 \mathrm{H}, \mathrm{m}: \mathrm{CH}_{2} \mathrm{CHCH}_{3}\right) ; 0.79$ (1H, m: 
$\left.\mathrm{CH}_{2} \mathrm{CHCH}-\mathrm{O}\right) ; 0.59\left(3 \mathrm{H}, \mathrm{d}, \mathrm{J}=7 \mathrm{~Hz}:\left(\mathrm{CH}_{3}\right)_{2} \mathrm{CH}\right) ; 0.46\left(3 \mathrm{H}, \mathrm{d}, \mathrm{J}=7 \mathrm{~Hz}:\left(\mathrm{CH}_{3}\right)_{2} \mathrm{CH}\right) .{ }^{13} \mathrm{C} \mathrm{NMR}(125.8$

$\left.\mathrm{MHz}, \mathrm{CDCl}_{3}\right), \delta(\mathrm{ppm}): 140.3\left(\mathrm{~d}, \mathrm{~J}_{\mathrm{PC}}=9.1 \mathrm{~Hz}:\right.$ quat $\left.\mathrm{PPh}_{2}\right) ; 138.0\left(\mathrm{~d}, \mathrm{~J}_{\mathrm{PC}}=8.3 \mathrm{~Hz}:\right.$ quat $\left.\mathrm{PPh}_{2}\right) ; 135.3(\mathrm{~d}$, $\left.\mathrm{J}_{\mathrm{PC}}=21.4 \mathrm{~Hz}: \mathrm{PPh}_{2}\right) ; 132.2\left(\mathrm{~d}, \mathrm{~J}_{\mathrm{PC}}=17.7 \mathrm{~Hz}: \mathrm{PPh}_{2}\right) ; 129.1\left(\mathrm{~s}: \mathrm{PPh}_{2}\right) ; 128.1\left(\mathrm{~d}, \mathrm{~J}_{\mathrm{PC}}=8 \mathrm{~Hz}: \mathrm{PPh}_{2}\right) ; 127.9$ $\left(\mathrm{d}, \mathrm{J}_{\mathrm{PC}}=5.8 \mathrm{~Hz}: \mathrm{PPh}_{2}\right) ; 127.6\left(\mathrm{~s}: \mathrm{PPh}_{2}\right) ; 90.3\left(\mathrm{~d}, \mathrm{~J}_{\mathrm{PC}}=26.1 \mathrm{~Hz}:\right.$ quat $\left.\mathrm{Cp}\right) ; 78.1$ (s: CH-O); $76.3(\mathrm{~d}, \mathrm{~J}=8$ Hz: quat Cp); 72.8 (d, J=3.4 Hz: subst Cp); 71.7 (d, J = 4.6 Hz: subst Cp); 70.3 (s: subst Cp); 69.5 (s: Cp); 64.8 (d, J = $\left.11 \mathrm{~Hz}: \mathrm{CpCH}_{2}\right) ; 48.1$ (s: CHCH-O); 40.0 (s: $\left.\mathrm{CH}_{2} \mathrm{CH}-\mathrm{O}\right) ; 34.6$ (s: $\left.\mathrm{CH}_{2} \mathrm{CHCH}_{3}\right) ; 31.3$ (s:

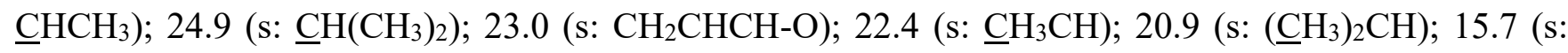
$\left.\left(\underline{\mathrm{CH}}_{3}\right)_{2} \mathrm{CH}\right) .{ }^{31} \mathrm{P} \mathrm{NMR}\left(202.5 \mathrm{MHz}, \mathrm{CDCl}_{3}\right), \delta(\mathrm{ppm}):-24.1$.

\subsection{Catalytic reaction conditions}

In a typical procedure, the ligand $(0.012 \mathrm{mmol}, 1.2 \mathrm{~mol} \%), \mathrm{Pd}_{2}(\mathrm{dba})_{3}(4.9 \mathrm{mg}, 0.005 \mathrm{mmol}, 1.1 \mathrm{~mol} \%)$, 1-naphthaleneboronic acid (1.2 mmol), cesium carbonate (750 mg, $2.030 \mathrm{mmol}, 2.3 \mathrm{~mol} \%$ ) and 1-bromo2-methylnaphthalene $(1.00 \mathrm{mmol})$ were introduced, under an argon stream, into a Schlenk tube containing $10 \mathrm{~mL}$ of toluene. The reaction mixture was stirred at 40,50 or $60^{\circ} \mathrm{C}$ for $24 \mathrm{~h}$ under an $\mathrm{Ar}$ atmosphere. Aliquots $(0.5 \mathrm{~mL})$ of the solution were taken using a polypropylene syringe. One $\mathrm{mL}$ of acidified water was added to each collected samples. After extraction by four portions of $1 \mathrm{~mL}$ of diethylether, the organic phase was then filtered through silica and the solvent was evaporated under reduced pressure. The residue was dissolved in $\mathrm{C}_{7} \mathrm{D}_{8}$ for the NMR analysis or in a hexane/isopropanol mixture (90/10) for the HPLC enantiomeric excess measurement.

\section{Acknowledgments}

We gratefully acknowledge the Centre National de la Recherche Scientifique (CNRS), the Institut Universitaire de France (IUF) for funding, and the "IUT A Paul-Sabatier" for offering accesses to laboratories and analytical equipments. 


\section{Figures and scheme}

Figure 1 - Examples of products containing a chiral biaryl unit.

Figure 2 - Selected ligands reported in asymmetric Suzuki-Miyaura coupling reactions.

Figure 3 - Structure of the chiral ligands used in this study.

Figure 4 - An ORTEP view of the structure of compound (S)-12a. Ellipsoids are drawn at the $30 \%$ probability level. The dichloromethane solvate and $H$ atoms have been omitted for clarity.

Figure 5 - Asymetric Suzuki-Miyaura coupling kinetics with ligands (R)-10 $\left(\square 4^{\circ} \mathrm{C}, \square 5^{\circ} \mathrm{C}\right.$ and $\left.\square 60^{\circ} \mathrm{C}\right), 11\left(\square 40^{\circ} \mathrm{C}, \square 50^{\circ} \mathrm{C}\right.$ and $\square 6^{\circ} \mathrm{C}$ ) and (R)-12 ( $\square 4^{\circ} \mathrm{C}, \square 5^{\circ} \mathrm{C}$ and $\square 60^{\circ} \mathrm{C}$ ).

Scheme 1 - Axial chirality induction via (i) planar, (ii) central or (iii) ligand chirality in the asymmetric Suzuki-Miyaura cross-coupling reaction.

Scheme 2 - Reagents and conditions for asymmetric Suzuki-Miyaura coupling of 2-methyl 1bromonaphtalene with naphthylboronic acid.

Scheme 3 - General pathway for the synthesis of ligands 10, 11 and 12. 
Figure 1 - Examples of products containing a chiral biaryl unit.

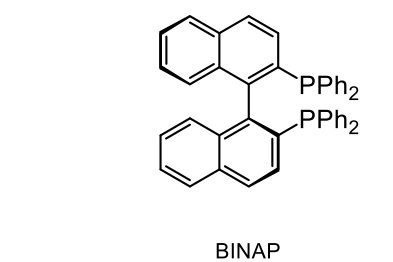

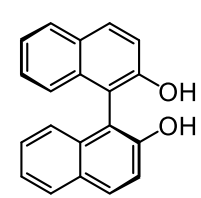

BINOL
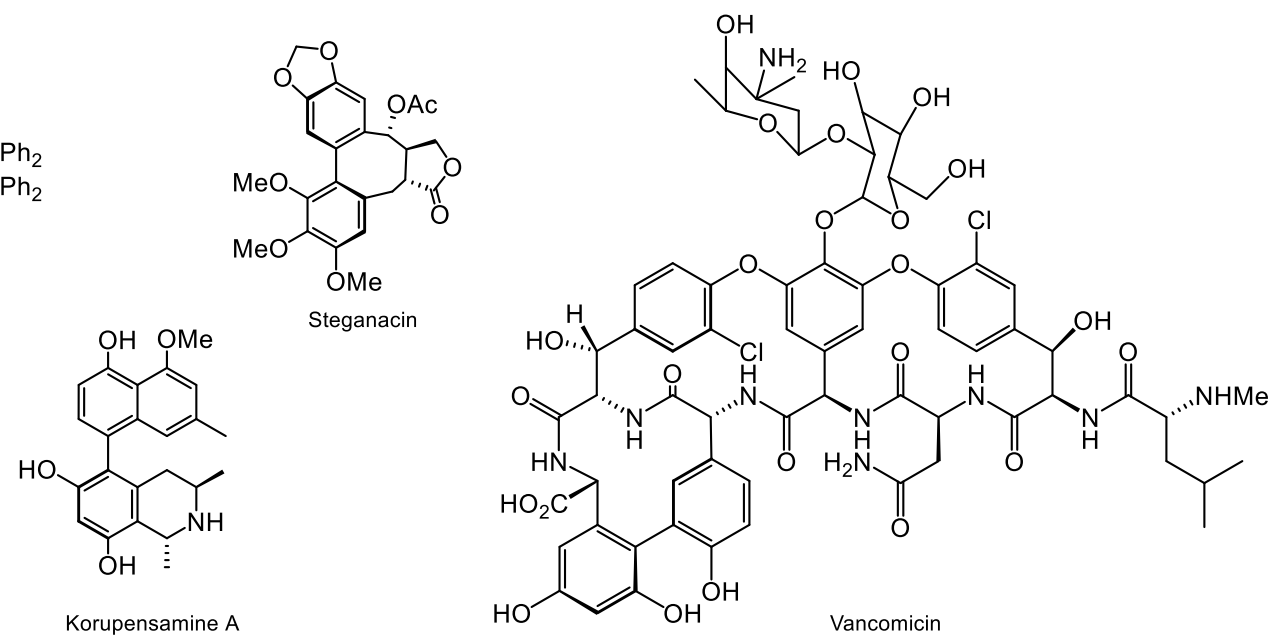

Figure 2 - Selected ligands reported in asymmetric Suzuki-Miyaura coupling reactions.
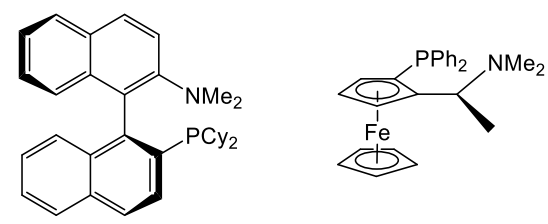

2

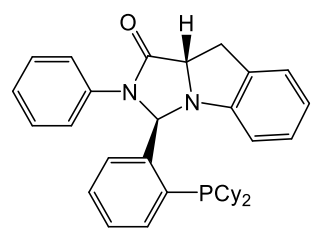

4

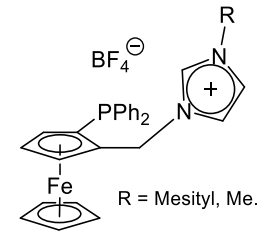

7

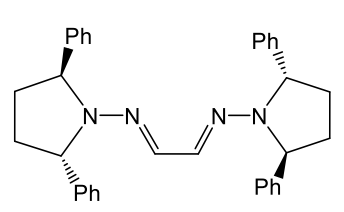

5

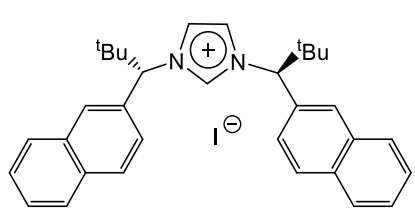

8

Figure 3 - Structure of the chiral ligands used in this study.

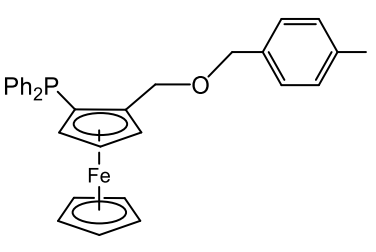

10

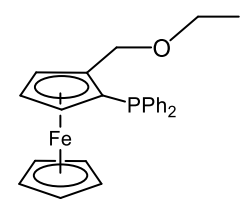

11

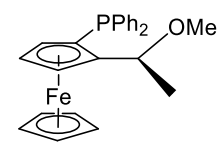

3

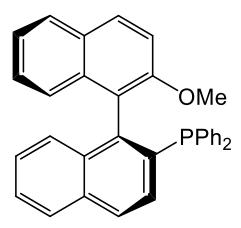

6 
Figure 4 - An ORTEP view of the structure of compound (S)-12a. Ellipsoids are drawn at the $30 \%$ probability level. The dichloromethane solvate and $\mathrm{H}$ atoms have been omitted for clarity.

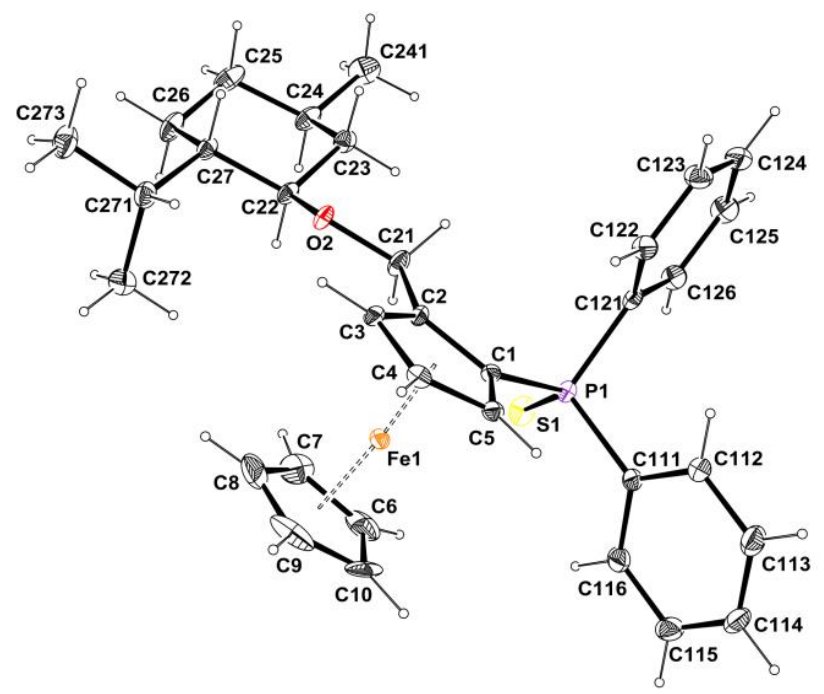

Figure 5 - Asymetric Suzuki-Miyaura coupling kinetics with ligands (R)-10 ( $\square 40^{\circ} \mathrm{C}, \square \mathbf{5 0}^{\circ} \mathrm{C}$ and $\left.\square 60^{\circ} \mathrm{C}\right), 11\left(\square 40^{\circ} \mathrm{C}, \square 50^{\circ} \mathrm{C}\right.$ and $\square 6^{\circ} \mathrm{C}$ ) and (R)-12 ( $\square 4^{\circ} \mathrm{C}, \square 5^{\circ} \mathrm{C}$ and $\square 6^{\circ} \mathrm{C}$ ).

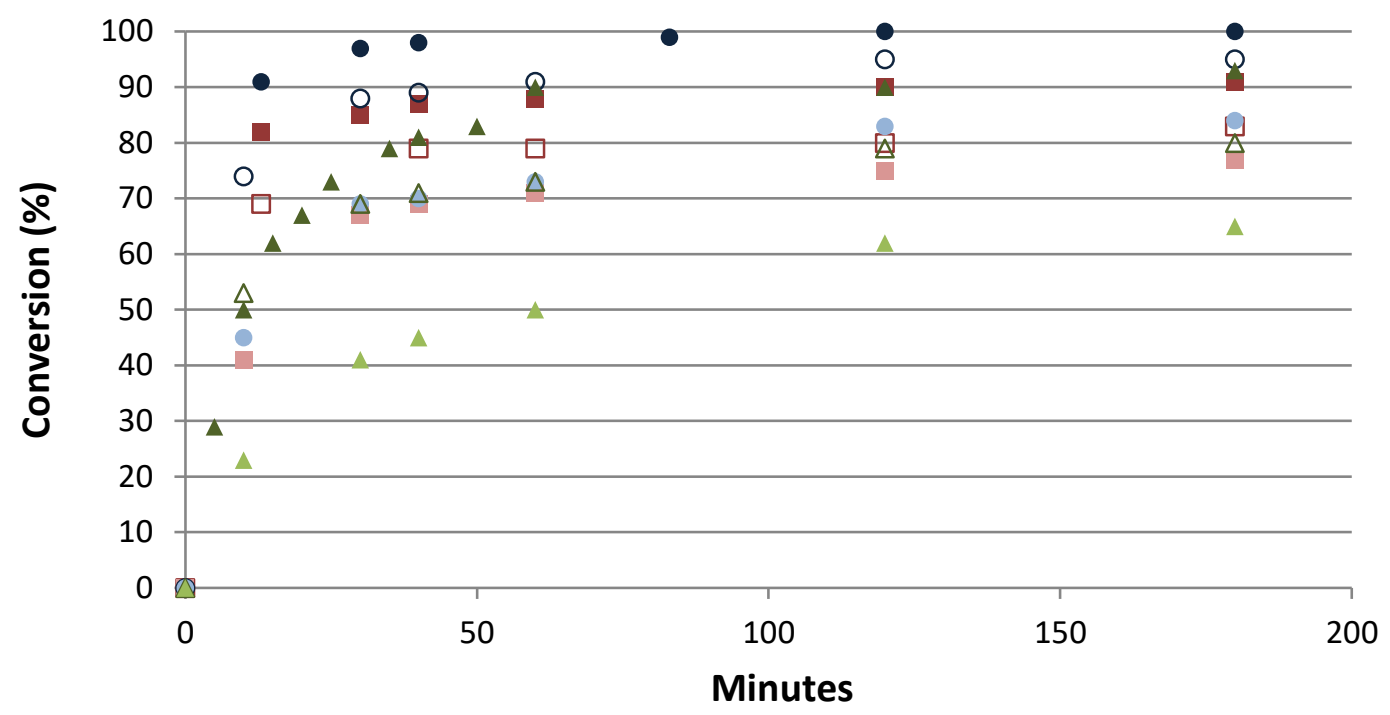


Scheme 1 - Axial chirality induction via (i) planar, (ii) central or (iii) ligand chirality in the asymmetric Suzuki-Miyaura coupling reaction.

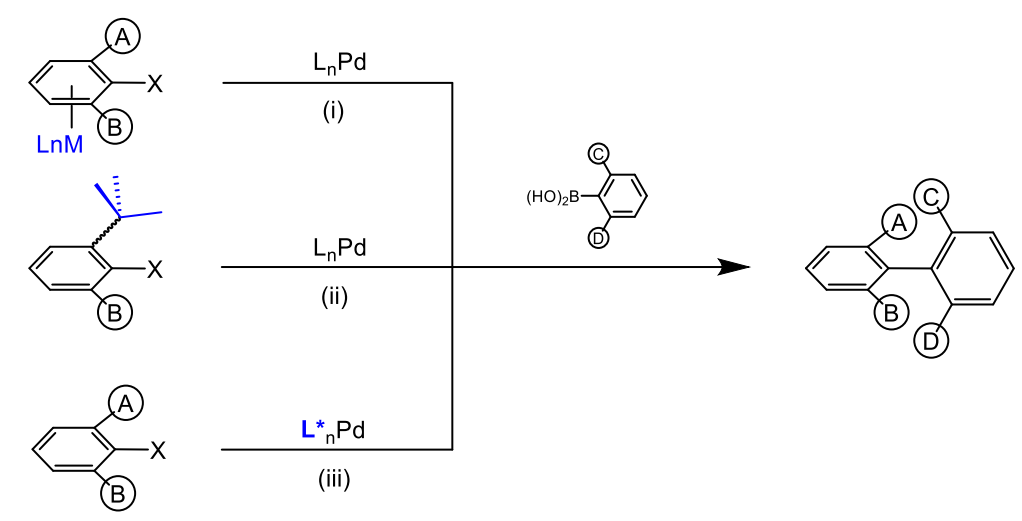

Scheme 2 - Reagents and conditions for asymmetric Suzuki- Miyaura coupling of 2-methyl 1bromonaphtalene with naphthylboronic acid.<smiles>Cc1ccc2ccccc2c1Br</smiles>

Scheme 3 - General pathway for the synthesis of ligands 10, 11 and 12.

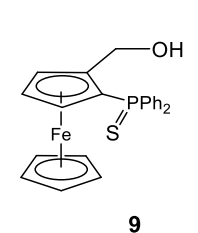

9

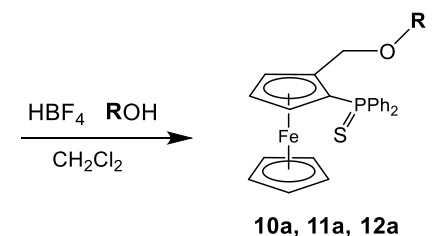

$10 \mathrm{a}, 11 \mathrm{a}, 12 \mathrm{a}$

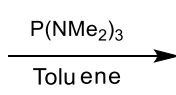

Toluene

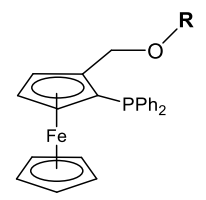

10, 11, 12

$10 \mathrm{a}, 10$




\section{References}

1 E. Colacino, J. Martinez, F. Lamaty, L.S. Patrikeeva, L.L. Khemchyan, V.P. Ananikov, I. Beletskaya, Coord. Chem. Rev. 256 (2012) 2893-2920.

2 a) N. Miyaura, A. Suzuki, Chem. Rev. 95 (1995) 2457-2483. b) A. Suzuki, J. Organomet. Chem. 576 (1999) 147-168.

3 S. Kotha, K. Lahiri, Eur. J. Org. Chem. (2007) 1221-1236.

4 M. Pagliaro, V. Pandarus, R. Ciriminna, F. Béland, P.D. Cara, Chem. Cat. Chem. 4 (2012) 432-445.

5 a) T.E. Jacks, D.T. Belmont, C.A. Briggs, N.M. Horne, G.D. Kanter, G.L. Karrick, J.J. Krikke, R.J. McCabe, J.G. Mustakis, T.N. Nanninga, G.S. Risedorph, R.E. Seamans, R. Skeean, D.D. Winkle, T.M. Zennie, Organic Process Research \& Development 8 (2004) 201-212. b) C.A. Busacca, D.R. Fandrick, J.J. Song, C.H. Senanayake, Adv. Synth. Catal. 353 (2011) 1825-1864.

6 a) S. Teo, Z. Weng, T.S.A. Hor, J. Organomet. Chem. 696 (2011)2928-2934. b) D. Schaarschmidt, H. Lang, Eur. J. Inorg. Chem. (2010) 4811-4821. c) L.-Y. Jung, S.-H. Tsai, F.-E. Hong, Organometallics 28 (2009) 6044-6053.

7 R. Martin, S.L. Buchwald, Accounts of Chemical Research 41 (2008) 1461-1473.

8 a) F. Godoy, C. Segarra, M. Poyatos, E. Peris, Organometallics 30 (2011) 684-688. b) X. Xu, B. Xu, Y. Li, S.H. Hong, Organometallics 29 (2011) 6343-6349. c) F.-T. Luo, H.-K. Lo, J. Organomet. Chem. 696 (2011) 1262-1265.

9 (a) R.J. Lundgren, M. Stradiotto, Chem. Eur. J. 18 (2012) 9758-9769. (b) A.B. Castillo, B.F. Perandones, E. Zangrando, S. Gladiali, C. Godard, C. Claver, J. Organomet. Chem. 734 (2013) 31 36.

10 O. Baudoin, Eur. J. Org. Chem. (2005) 4223-4229.

11 J. Yin, S.L. Buchwald, J. Am. Chem. Soc. 122 (2000) 12051-12052.

12 A.N. Cammidge, V.L. Crépy, Chem. Commun. (2000) 1723-1724. 
13 K. Sawai, R. Tatumi, T. Nakahodo, H. Fujihara, Angew. Chem. Int. Ed. 47 (2008) 6917-6919.

14 A. Bermejo, A. Ros, R. Fernandez, J.M. Lassaletta, J. Am. Chem. Soc. 130 (2008) 15798-15799.

15 (a) N. Debono, A. Labande, E. Manoury, J.-C. Daran, R. Poli, Organometallics 29 (2010) 18791882. (b) P. Loxq, N. Debono, S. Gülcemal, J.-C. Daran, E. Manoury, R. Poli, B. Çetinkaya, A. Labande, New Journal of Chemistry 38 (2014) 338-347.

16 L. Benhamou, C. Besnard, E.P. Kündig, Organometallics 33 (2014) 260-266.

17 L. WU, A. Salvador, A. Ou, M.W. Shi, B.W. Skelton, R. Dorta, Synlett 24 (2013) 1215-1220.

18 T. Yamamoto, Y. Akai, Y. Nagata, M. Suginome, Angew. Chem. Int. Ed. 50 (2011) 8844-8847.

19 W. Tang, N.D. Patel, G. Xu, X. Xu, J. Savoie, S. Ma, M.-H. Hao, S. Keshipeddy, A. G. Capacci, X. Wei, Y. Zhang, J.J. Gao, W. Li, S. Rodriguez, B.Z. Lu, N.K. Yee, C.H. Senanayake, Organic Letters 14 (2012) 2258-2261.

20 Y. Uozumi, Y. Matsuura, T. Arakawa, Y.M.A. Yamada, Angew. Chem. Int. Ed. 48 (2009) 27082710 .

21 Y. Zhou, S. Wang, W. Wu, Q. Li, Y. He, Y. Zhuang, L. Li, J. Pang, Z. Zhou, L. Qiu, Organic Letters 15 (2013) 5508-5511.

22 C. Audin, J.-C. Daran, E. Deydier, E. Manoury, R. Poli, C. R. Chimie 13 (2010) 890-899.

23 R.C.J. Atkinson, V.C. Gibson, N.J. Long, A.J.P. White, D.J. Williams, Organometallics 23 (2004) 2744-2752.

24 S. Teo, Z. Wenig, T. S. A. Hor, Organometallics 25 (2006) 1199-1205.

25 N. Mateus, L. Routaboul, J.-C. Daran, E. Manoury, J. Organomet. Chem. 691 (2006) 2297-2310.

26 M.-M. Wei, C. Audin, E. Manoury, E. Deydier, J.-C. Daran, Acta Cryst. (2014) C70.

27 A. Herrbach, A. Marinetti, O. Baudoin, D. Guénard, F. Guéritte, J. Org. Chem. 68 (2003) $4897-$ 4905.

28 A.N. Cammidge, K.V.L. Crépy, Tetrahedron, 60 (2004) 4377-4386.

29 X. Shen, G.O. Jones, A. Watson, B. Bhayana, S.L. Buchwald, J. Am. Chem. Soc. 132 (2010) 1127811287. 
30 T. Hayashi, T. Mise, M. Fukushima, M. Kagotani, N. Nagashima, Y. Hamada, A. Matsumoto, S. Kawakami, M. Konishi, K. Yamamoto, M. Kumada, Bull. Chem. Soc. Jpn. 53 (1980) 1138-1151.

31 Altomare, A., Burla, M. C., Camalli, M., Cascarano, G. L., Giacovazzo, C., Guagliardi, A., Moliterni, A. G. G., Polidori, G. \& Spagna, R. (1999). SIR97- a program for automatic solution of crystal structures by direct methods. J. Appl. Cryst. 32, 115-119.

32 Sheldrick, G. M. (2013). SHELXL-2013, University of Göttingen, Germany

33 Flack, H. D. (1983). Acta Cryst. A39, 876-881.

34 a) Farrugia, L. J. (1997). ORTEP-3 for Windows, J. Appl. Cryst. 30, 565. b) Burnett, M. N. \& Johnson, C. K. (1996). ORTEPIII. Report ORNL-6895. Oak Ridge National Laboratory, Tennessee, USA 